\title{
An Incidental Finding of a High Vascularized Retroperitoneal Mass in a Young Woman
}

\section{Marta Jimenez Toscano, Federico Ochando Cerdá, Luis De Benito Fernandez, Enrique Puras Malagaray Laura Vega Lopez, Santiago Linacero Martin, Patricia Dhimes, Jose Maria Fernandez Cebrian Antonio Quintans Rodriguez}

How to cite this article: Toscano MJ, Cerdá FO, De Benito Fernandez L, Malagaray EP, Lopez LV, Martin SL, Dhimes P Cebrian JMF, Rodriguez AQ. An Incidental Finding of a High Vascularized Retroperitoneal Mass in a Young Woman. World J Endoc Surg 2012;4(2):85-86.

Source of support: Nil

Conflict of interest: None

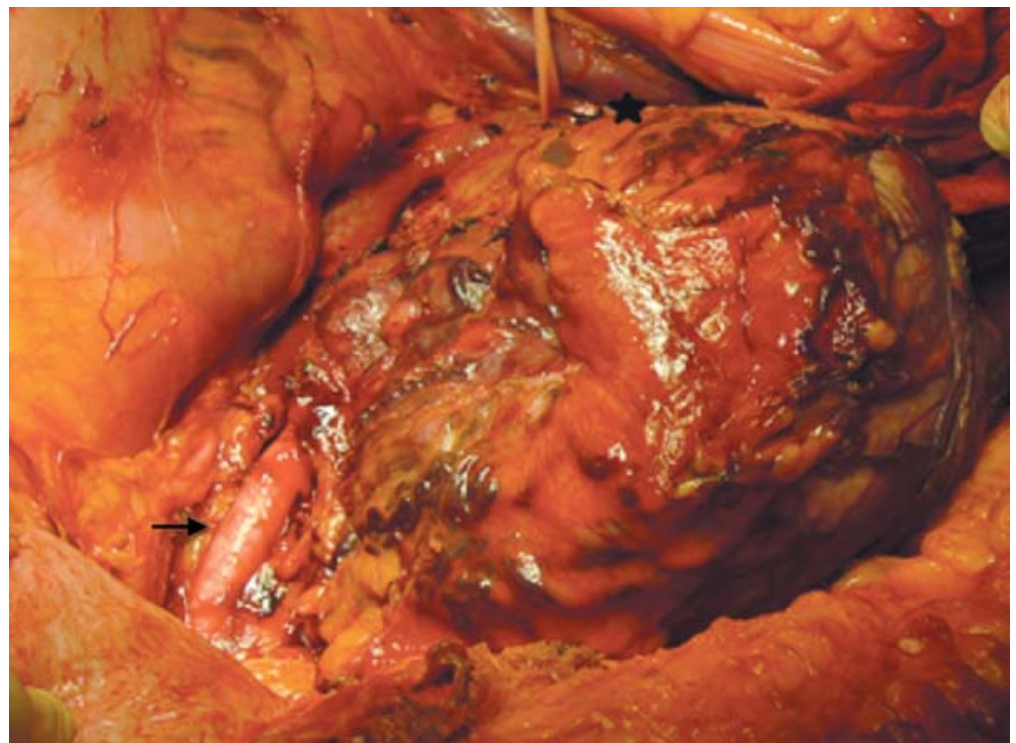

Fig. 1: Macroscopic finding revealed a $14 \mathrm{~cm}$ diameter mass encapsulated without invasion into the surrounding tissues. A radical excision of the tumoral mass was made (black arrow: left iliac artery; asterisk: left renal artery)

\section{INTRODUCTION}

Paragangliomas are endocrine tumors derived from the chromaffin cell of the autonomous nervous system. Its localization out of the adrenal gland is extremely rare. We present a 44-year-old woman with 1 month of abdominal pain and weight's lost of $31 \mathrm{~kg}$ in a year. A solid heterogeneous mass was discovered in a computerized tomography $(14 \times 14 \times 12 \mathrm{~cm}$ with cyst and necrosis components and peripheral enhance; Fig. 1). In an abdominal angio-RM, the tumor displaced the left kidney and the aorta next to the pancreas and compressing psoas muscle. A complex vascularization was observed in an arteriography from inferior mesenteric artery, vertebral arteries, celiac trunk and right kidney artery. Epinephrine and dopamine were in range of normality but norepinephrine in plasma was $>823 \mathrm{pg} / \mathrm{ml}$ (0.0-370.0). A preoperative embolization to reduce the vascular supply was planned with microspheres of 300 to $500 \mu$ and polyvinyl alcohol. A radical excision of the tumoral mass was made preserving adjacent organs and vascularization. The diagnosis was confirmed with a inmunohistochemical study positive for vimentina, CD 56 and sinaptofisina and without evidence of malignancy. One year after she remains abdominal metastatic illness confirmed by abdominal single photon emission computed tomography with radioisotope injection (123-I-MIBG).

\section{ABOUT THE AUTHORS}

\section{Marta Jimenez Toscano (Corresponding Author)}

Department of Surgery, Hospital Universitario Fundacion Alcorcon, Alcorcon, Spain, e-mail: martajtoscano@yahoo.es 


\section{Federico Ochando Cerdá}

Department of Surgery, Hospital Universitario Fundacion Alcorcon, Alcorcon, Spain

\section{Luis De Benito Fernandez}

Department of Vascular Surgery, Hospital Universitario Fundacion Alcorcon, Alcorcon, Spain

\section{Enrique Puras Malagaray}

Department of Vascular Surgery, Hospital Universitario Fundacion Alcorcon, Alcorcon, Spain

\section{Laura Vega Lopez}

Department of Surgery, Hospital Universitario Fundacion Alcorcon, Alcorcon, Spain

\section{Santiago Linacero Martin}

Department of Surgery, Hospital Universitario Fundacion Alcorcon, Alcorcon, Spain

\section{Patricia Dhimes}

Department of Pathology, Hospital Universitario Fundacion Alcorcon, Alcorcon, Spain

\section{Jose Maria Fernandez Cebrian}

Department of Surgery, Hospital Universitario Fundacion Alcorcon, Alcorcon, Spain

\section{Antonio Quintans Rodriguez}

Department of Surgery, Hospital Universitario Fundacion Alcorcon, Alcorcon, Spain 